\title{
Churches and the Economy of Sämoa
}

\author{
Cluny Macpherson and La'avasa Macpherson
}

Since Christian missions arrived in Sāmoa early in the nineteenth century,
the churches they founded have achieved a central place in Samoan soci-
ety. Methodists commenced evangelical work at Satupa 'itea in I 828 ; the
London Missionary Society (LMS) set up a mission at Sapapali'i in I 830
(which became the Congregational Christian Church in Samoa [CCCS]);
and Roman Catholic presence was established in Apia in I 845 . Conver-
sions from a precontact polytheistic religion to a monotheistic one were
rapid and completed by the early I 85 os. The early work by these three
denominations, referred to as the mainstream churches, ensured that they
became, and remain, the largest and most influential denominations in
Sāmoa.

Other denominations soon followed. The Church of Jesus Christ of Latter-day Saints established a mission in I 888; the Seventh-day Adventist church established a presence in $\mathrm{I} 897$. A growing number of evangelical churches, such as the Assemblies of God, have been instituted in Sāmoa since the Second World War. But the early and dramatic conversions achieved by the agents of the London Missionary Society and the Methodist and Roman Catholic churches secured a central place for them in Samoan society, and later arrivals have, until recently, made only limited inroads into the support of these mainstream churches (see table I).

\section{The Church in Contemporary Samoan Society}

As one would expect in a nation whose motto is "Samoa is founded on God" (Fa'avae i le Atua Samoa), 99.9 percent of Samoans reported nominal adherence to one of the Christian denominations in the 200I Samoan census. For most, however, commitment to their churches is anything but nominal: it is intense and active, as reflected in the high levels of atten-

The Contemporary Pacific, Volume 23, Number 2, 304-337

(C) 20 I I by University of Hawai'i Press 
dance at church services, participation in church-related activities, and contributions of various forms of support for the churches' work.

While Christian beliefs and practices are central elements of individuals' worldviews and lifestyles, the churches also play a central role in the social, political, educational, and economic life of the Samoan nation. Many national politicians, civil servants, and senior matai (titleholders) are also officeholders in churches. Their involvement in the churches ensures a secular awareness of, and political support for, churches' aspirations. This closeness is reflected in the routine inclusion of church leaders in the government's stakeholder consultations on national planning and

Table I. Church Membership in Sāmoa, I99I and 200 I

\begin{tabular}{lcc}
\hline & \multicolumn{2}{c}{ Percentage of Population } \\
\cline { 2 - 3 } Denomination & 1991 & 2001 \\
\hline Congregational Christian Church in Samoa & 42.6 & 34.8 \\
Roman Catholic Church & 20.8 & 19.6 \\
Methodist Church of Samoa & 16.9 & 15.0 \\
Jesus Christ of Latter-day Saints & 10.0 & 12.7 \\
Seventh-day Adventist Church & 3.0 & 3.5 \\
Other* & 5.9 & 14.3 \\
Total† & 99.2 & 99.9 \\
\hline
\end{tabular}

Sources: State Department 2003; So'o, Va'a, and Lafotanoa 2006, 24.

* For 200I, these include the Assembly of God (6.6 percent); Jehovah's Witnesses (0.8 percent); Congregational Christian Church of Jesus in Sāmoa (I.० percent); Nazarene ( 0.4 percent); Protestant ( 0.2 percent); Baptist ( 0.2 percent); Full Gospel (0.8 percent); Voice of Christ (0.4 percent); Worship Centre (I.3 percent); Peace Chapel (I.3 percent); Anglican Church ( 0.2 percent); Community Church ( 0.3 percent); Elim Church (O.I percent); Sāmoa Evangelism (O.I percent); A'oga Tusi Pa'ia (0.4 percent); Baha'i (0.5 percent); Muslim ( 0.0 percent); and others (0.I percent). Due to rounding, these individual percentages total more than the actual I 4.3 percent for the combined church memberships.

† Due to rounding, figures do not add up to roo percent. 
in the recognition of their aspirations and roles in its biennial economic strategy statements (see, eg, Treasury Department 2000).

This national commitment to Christian religion has been a significant factor in the social and political stability that has characterized Sāmoa since it achieved constitutional independence in 1962. As the Reverend Fepa'i Fiu Kolia, secretary of Sāmoa's National Council of Churches, noted, "Since independence in 1962, the church and state have worked side by side to develop the Samoan people. Government leaders are sometimes church leaders as well, which therefore reinforces the mutual beneficial relationship between these two important sectors of society. Hence, democracy, culture and Christian values have integrated well in a manner that is acceptable to the local community" (2006, I37).

The influence of churches, and of Christian teaching, in the organization and management of village polities is also significant in the maintenance of order that generally characterizes village life in Sāmoa. This view is summarized in a key government policy document: "The position of the church in the community can be quite influential. ... the potential influential standing and the extensive outreach of the church within the community makes it a valuable vehicle to drive pro-harmony strategies. Indeed the cultural structures should work hand in hand with the church in promoting social harmony in the communities" (Treasury Department 2002, 20). ${ }^{1}$

But this central church role comes at a cost: contributions made to churches impact both village and national economies. Our interest in the issue arose from casual discussions with relatives and friends in Sāmoa who outlined plans for agricultural development projects and small businesses that they claimed they were unable to start, and in some cases to operate, because of ongoing financial commitments to their churches.

Some expatriate Samoans expressed frustration that remittances they sent to provide investment capital for family and friends had been given instead to churches. They noted that attempts (some over many years) to provide relations with means of becoming economically self-sufficient were routinely frustrated by church-related demands and that their relations remained dependent on remittances to live.

Still others, in Sāmoa and abroad, noted that even though they managed their own giving, they were affected by others' contributions to churches. When, for instance, relatives' and friends' church contributions resulted in financial overcommitment, they would borrow from those around them to meet basic expenses. This borrowing, in turn, affected lenders' ability to meet their own expenses. These claims echoed our experiences and led 
us to consider how resources consumed by churches in Sāmoa influence village and national development. ${ }^{2}$

\section{The Church and the Economy in SĀmoa}

Cash, labor, and goods that parishioners give to their pastors, and to the churches they serve, are not available for investment in small business or agricultural development or for postponed investments such as education and training. These cash, labor, and commodity commitments to churches limit villagers' ability to accumulate capital, which, in turn, limits the range and scale of economic investment options that are realistically available to them.

Cash contributed to churches effectively limits the capacity of individuals, families, and village groups to save or to acquire assets that could be used as collateral for commercial loans to establish and operate commercial ventures. ${ }^{3}$ Consequently, many are necessarily limited to obtaining loans from microfinance providers, or to borrowing against their contributions to the national superannuation fund ${ }^{4}$-options that, while valuable, seriously restrict the range and scale of village-level investment activity. Cash contribution requirements may also leave existing small businesses vulnerable by constraining operators' ability to retain profits for reinvestment and expansion. Labor contributed to churches reduces the labor available to individuals and families to commit to revenue-generating activity or to their own businesses. Finally, goods given to churches reduce the amount that families can either sell or invest to increase their income. These, in turn, have consequences for the trajectory of the national economy.

The relatively low incomes in village-based primary production, the diversion of significant portions of those incomes to the church, and the limited opportunities available to increase them mean that many young people prefer not to invest labor in the village, placing their hopes instead in moving to urban centers such as Apia or to the higher-wage economies of Australia and New Zealand. Their migration to Apia often results in declining primary production and either underemployment or unemployment. At the same time, the steadily increasing urban population requires additional government investment in urban infrastructure while contributing little to government revenue.

Constraints on domestic savings and domestic investment capital limit national economic growth, which, in turn, restricts the government's ability to fund its activity from growth. Low incomes and low growth rates 
have further limited the government's capacity to expand its tax base and its taxation revenue. This situation results in continued dependence on development assistance from international financial institutions, and burdens the country with the costs of borrowing abroad to finance expenditure that might otherwise be funded locally. These borrowings, which often come with conditionalities, may, in turn, impose constraints on national sovereignty.

Our analysis here makes no comment on the possibility that donors regard their contributions to churches as forms of religious or sociopolitical "investment" and, in the Samoan worldview, rank more highly in their priorities than narrowly conceived "economic" investment. In fact, we acknowledge that the reverse view holds for many Samoans, who see religious commitment as the key to their social and economic well-being. As Rev Fepa'i Kolia noted, "Often, the established churches are challenged by members of the community who claim that financial and other material demands of the church are contributing to poverty in Sāmoa. It is a debatable view. The general view of many Samoans, however, is that great spirituality means abundant prosperity" (2006, I37).

This analysis recognizes the possibility that definitions of "security" are culturally bound. It is readily apparent in Sāmoa that the social and spiritual security that donors derive from their support for the Church is more important to them than the returns that might be derived from the investment of the same amount of money in, say, a financial institution. The religious and sociopolitical "dividends" derived from contributions to churches are considered more significant and more certain, and they are valued more highly than those derived from financial investments and calculated on such narrowly conceived indices as rates of return on capital. This analysis passes no comment on this view of the nature or sources of "security."

Instead, this analysis seeks simply to profile the organization of the churches and the support that Samoans commit to them, to outline issues that surround the calculation of the "value" of that support, to provide an estimate of the value of contributions to churches, and to consider its possible significance for the trajectory of development in village and national economies.

\section{The Organization of Samoan Churches}

Three major denominations-the Congregational Christian Church in Samoa, the Roman Catholic Church, and the Methodist Church of Samoa 
$(\mathrm{MCS})^{5}$ - together enjoyed the support of nearly 70 percent of the population in 200I and are the mainstays of Sāmoa's National Council of Churches. These three churches have central offices around Apia, which provide support services such as financial management, church record maintenance, religious publishing, production of instructional material, and management of church education systems and theological training institutions. Each of these denominations divides the nation into districts (pulega or sinoti), which loosely correspond with traditional political districts. The districts exist primarily for administrative purposes and assume practical significance only at certain times of the year when villages' contributions are consolidated into district ones, as shown later in this article. Each district comprises a number of village congregations, or 'aulotu. For most people, for most of the year, religious activity focuses on the village congregation in which they worship.

Three other churches-the Church of Jesus Christ of Latter-day Saints, the Seventh-day Adventists, and the Assemblies of God-accounted for 22.8 percent of the population in $200 \mathrm{I}$. These also have central administrations, districts, and village-based congregations, but they differ from the major churches in that they have linkages with metropolitan parent churches that provide significant support for Samoan congregations but also constrain their autonomy. This support takes the form of subsidies for transnational churches' building programs, provision of religious and secular education, training for the pastorate, and support for missionary activity. Only urban areas and some of the more "progressive" villages have allowed these churches in, which limits their national presence and influence. These denominations' populations are growing steadily and their presence, and influence, is also expanding (Goman 2006; Thornton, Kerslake, and Binns 2010).

\section{Published INFORMATION CONCERNING Church Contributions}

Given the social and economic significance of these contributions, we had assumed that figures would be readily available either in academic studies or in church or government documents. The churches do not make their national data publicly available, and, since only certain types of contributions collected in the name of the church pass through the central churches' accounts, the data at their disposal would constitute an incomplete record of the value of all contributions made to the churches.

A review of studies turned up only two early estimates: Brian Lock- 
wood's I970 study of four villages provided figures for cash contributions (Lockwood I97I), and David C Pitt's I970 three-village study contained estimates of the numbers of hours of work provided to the church by members in those villages (Pitt I970). But these well-documented classical studies, while interesting, were of limited value because they were forty years old and were completed before large-scale migration and remittances from emigrants transformed the village economy (Macpherson and Macpherson 2009).

Some studies of the scale, sustainability, and use of remittances from Samoan emigrants in New Zealand and Australia, respectively, have addressed the use of remittances to meet customary obligations, including religious ones, but made no estimate of the portion of remittances used to meet church commitments. One article pointed to the significance of macroeconomic policies in migrant Samoan enclaves in sustaining remittance levels and expenditure patterns (Macpherson 1992). Another comprehensive study of remittances from Samoan migrants in Australia looked at the range of "social uses" to which remittances were put and how various uses were prioritized (Brown and Ahlburg 1999).

Other studies, including a number by Samoan economists ${ }^{6}$ - whom one might expect to be aware of and interested in these figures-either conflated contributions to church and customary obligations, or, more recently, have focused on the macroeconomy and macroeconomic settings (Sialaoa 200I, 2003). Only one recent report, by a research team led by Samoan sociologist Maria Kerslake, contained an estimate of the value of contributions to the Church (Kerslake 2004). The value of this figure was limited by the size of the sample and the fact that their study was carried out on Savai'i, where both mean and medium incomes are typically lower than on Upolu (see SBS 2002, table 2.2).

In 1997 and 2002, the United Nations Development Program and the Samoan Government's Department of Statistics carried out two larger, well-organized Household Income and Expenditure Surveys (HIES) and collected significantly more data than had previously been available (SBS 1997, 2002). The Sämoa National Human Development Report, edited by Le'apai Lau Asofou So'o, Unasa Leulu Felise Va'a, and Telesia Lafotanoa (2006), summarized the 1997 HIEs findings on church and customary obligations in the following ways: " "Samoan values are closely knitted with her strong religious convictions as evident by regular societal financial contributions amounting to the largest of household expenditures at SATIm per week" (Salele 2006, I03). "The I997 HIES recorded about 
SATI09,000 a week, SAT5.7 million a year, was spent on church obligations and correspondingly, about SAT668,000 a week, SAT34.8 million a year, was being spent on cultural obligations" (Muagututi'a 2006, 62). ${ }^{8}$

The same report also commented on the findings from the 2002 Household Income and Expenditure Survey: "The 2002 HIES recorded that much more was spent on cultural and church obligations. On an average, about SATI million a week had been spent on both cultural and church obligations, about SAT 52 million a year. On the basis of the 1997 distribution, it is estimated that in 2002 , approximately SAT 44.7 million was spent on cultural obligations and SAT5.3 million on church obligatory costs" (Muagututi'a 2006, 62).

This final figure, SAT5.3 million for church contributions, is problematic: if the 1997 proportions for church and cultural obligations, respectively, were maintained in 2002, annual church costs would be around SAT7.33 million and the weekly figure would be around SATI4I,OOO (see table 2). Support for this estimate is found elsewhere in the same report where a figure provided by churches is offered: "Monetary offerings by

Table 2. Estimates of Annual Church and Cultural Obligations in Sāmoa

1997

\begin{tabular}{lcc} 
Type of Obligation & Amount (in Millions of sAT) & Proportion of Total \\
\hline Church & 5.7 & 14.1 \\
Cultural & 34.8 & 85.9 \\
Total & 40.5 & 100.0 \\
\hline
\end{tabular}

2002

\begin{tabular}{lcc}
\hline Type of Obligation & Amount (in Millions of sAT) & Proportion of Total \\
\hline Church & 7.3 & 14.1 \\
Cultural & 44.7 & 85.9 \\
Total & 52.0 & 100.0 \\
\hline
\end{tabular}

Source: Muagututi'a 2006, 62. 
the biggest denominations range from SAT $5-8$ million per annum, according to Reverends Afa Tyrell and Elisaia Kolia, Treasurers of the CCCS and MCS respectively" (Kolia 2006, I39).

Even these higher figures, however, seem to underestimate the value of "monetary offerings." There are some 362 villages in Sāmoa (Economic Development Department 1973). Each has at least one mainstream church, and some villages have more than one. In 2005 , we could not find a village in which the fortnightly offering was less than SATI, , o, and many reported significantly larger amounts, with a few large, urban villages giving as much as SAT8,000 per fortnight. From figures collected from a sample of villages, we calculated a median figure of SATI, 500 per fortnight. A national estimate, based on 362 congregations giving a fortnightly offering of SATI, 500 , produced a fortnightly total of SAT 543,000 , or SAT27I,500 per week-nearly two and a half times the weekly estimate derived from the I 997 HIES data (SATI09,000) and almost twice the weekly estimate derived from the 2002 HIEs figures (SATI 4I,O0O).

The HIEs estimates of cash contributions may have resulted from the ways in which data were collected and edited. The value of noncash contributions is considerable and, for reasons outlined above, can have a significant impact on the village economy. The Household Income and Expenditure Surveys recorded high levels of exchange of goods and services within the economy, but they did not identify the value of labor and goods given to the church. These concerns led us to consider how we might calculate a more accurate value of contributions made to the church, and identify some of the consequences of these patterns of giving for individuals, villages, and the nation.

\section{Estimating Churches' Impact on the Samoan Economy}

To understand these impacts, it is necessary to identify the various components of contributions to churches and then to estimate their value. Identifying the elements of contributions is relatively straightforward; however, estimating their values is more complicated because of the ways in which the contributions are collected and managed in different denominations.

Congregational, Methodist, and, more recently, Catholic churches in Sāmoa routinely make public the amounts collected as regular "freewill offerings" (alofa or peleti) and as special offerings (taulaga) (Thornton, Kerslake, and Binns 2010). ${ }^{9}$ Individual families' contributions (which are read out during services) and village congregations' contributions to district totals (which are read out during church meetings) have become 
proxy indices of villages' religious commitment and of their wealth and are discussed in the village and beyond. People routinely speculate about the possible social and political significance of any variations in "standard" patterns of giving. The same is true of contributions made to extraordinary projects such as church building. When mainstream congregations build churches, funds come from villagers, ${ }^{10}$ from expatriate villagers through tusigaigoa, ${ }^{11}$ and from gifts made by guests (ta'alolo) invited to the church opening ceremonies (fa'aulufalega). The values of these gifts are announced and are widely discussed within congregations, because they reflect on village families' ability to mobilize networks within and beyond the village and have broader sociopolitical significance. As a consequence, significant amounts of data are readily available from these three denominations. But even these data underestimate the real value of these projects: for various reasons, the value of other significant contributions, including the labor provided by the village congregation during building projects, is not routinely estimated or included in these formal lists. ${ }^{12}$

Certain denominations, however, treat giving as a matter of personal conscience and do not publicly reveal members' contributions. These include the tithing churches-the Church of Jesus Christ of Latter-day Saints and the Seventh-day Adventists-which together claimed some I6.2 percent of the population in 2006; small churches, such as the Apia Protestant Church; and non-tithing denominations, such as the Assemblies of God. Further, construction costs incurred in these churches are met jointly by local congregations and parent churches abroad. The value of local contributions to these construction projects is not readily available.

For our purposes, it is fortunate that nearly 70 percent of the population belong to mainstream churches for which basic data are more readily available. This reality has shaped our approach to calculation. Rather than attempting to calculate the value of contributions in all churches in Sāmoa, from this point this study attempts to establish the value of contributions to the three mainstream churches. While this approach will clearly underestimate the total value of contributions made to all churches, it should be instructive and provide at least a minimum value and starting point for discussion. ${ }^{13}$

\section{Elements of Contributions to Mainstream Churches}

The first set comprises regular contributions in cash, labor, and kind for the basic maintenance of the village pastor, or catechist, and his family. ${ }^{14} \mathrm{~A}$ second set comprises casual contributions made to pastors for performance 
of various spiritual and secular services in the course of daily rounds. A third set comprises annual contributions in cash and kind, made through committees that manage congregations' affairs, for the maintenance and development of the village-owned properties that the pastors use and for the work of the national churches in Sāmoa and abroad. A fourth set comprises extraordinary contributions of cash and labor made to periodic church-sponsored construction projects. Each set is outlined below.

\section{Regular Maintenance Contributions}

Mainstream congregations provide the following for their pastors' use:

- fortnightly freewill cash offering (alofa or peleti)

- rent-free residence

- rent-free land on which to grow food crops

- free labor to tend food gardens

- free labor for household work

- food contributions

- payment of utility bills

- fuel and vehicle maintenance

Village children may provide domestic and plantation labor for pastors' households when requested. Women contribute significant amounts of labor, as the Sämoa National Human Development Report noted: "Women have always been the backbone of the church. Through independent organizations within the church they form at the parish and national levels, the women contribute immensely to such things as facilities for the use of the pastors and their families at the parish level, construction and maintenance of some church facilities, cleanliness around church premises and so forth" (So'o, Va'a, and Latofanoa 2006, 4I). Families also routinely give food, from their own production and from ceremonial distributions, to their pastors' household out of respect and obedience to scripture. While formal minimum or maximum amounts are not usually set for any of these contributions, informal sociopolitical competition between families (matāfale) within village congregations ensures that both total and relative amounts either remain fairly stable or increase over time. ${ }^{15}$

In 2005, data were collected from twelve mainstream congregations in villages of various sizes and locations, with varying amounts of agricultural land and forms and levels of participation in the wage economy, all of which influence the total wealth in the village. From these data, we identified four village "types": 
I) large, high-income urban villages in which a high proportion of relatively well-paid urban wage and salary earners resided

2) medium income, peri-urban villages in which a relatively high proportion of urban wage and salary workers resided

3) mid-size, medium-income rural villages that derived much of their income from commercial-scale agriculture but also some from the wages of villagers living and working in urban centers

4) small, rural villages with limited land and marine resources that derived income from agriculture, handicraft production, and wages from villagers living and working in urban centers

One village of each type was then selected, and figures from the representative village types were collected to produce "surrogate" cases. Two villages were selected from the Apia Urban and the Northwest Upolu areas, which together account for 40 percent of the total population and 70 percent of the country's gross domestic product, and two rural villages were chosen on the bases of size and economic mix. Data from these representative villages were then used to calculate the medians that form the basis for the national estimates.

The ranges that emerged were considerable: the fortnightly freewill offerings, for instance, ranged from SATI, 000 to SAT8,000 per village, and similar ranges were reflected in other categories of maintenance contributions. The ranges reflected, in part, villages' demographic profiles, factor endowments, and the length of service and "performance" of the pastor. ${ }^{16}$ But these variables were to some extent offset by the size of villages' expatriate populations, which we could not establish but which have a profound effect on the amount of cash and goods available to the village and to the church (Macpherson and Macpherson 2009).

A mid-range figure for maintenance contributions was calculated for this small but representative sample for $2005 \cdot{ }^{17}$ These were SAT2,500 per fortnight as an alofa or peleti to the pastor; a further SATI 50 per fortnight to meet the pastor's family's living expenses; and Ioo hours of labor, valued at SATI.60 per hour per fortnight. ${ }^{18}$ These were then multiplied by the total number of villages (362) to get a national, annual figure of SAT24,4I3,280 (table 3).

\section{Casual Gifts}

Pastors receive gifts for officiating at religious and secular events. Religious services for their parishioners include visiting the sick and performing wedding services, funeral services, baptisms, blessings at building 
Table 3. Estimated Value of Median Village Maintenance Contributions (sAT)

\begin{tabular}{lrrr}
\hline Category & Fortnightly & Monthly & Annually \\
\hline Offering & 2,500 & 5,000 & 60,000 \\
Expenses & 150 & 300 & 3,600 \\
Labor & 160 & 320 & 3,840 \\
Estimate per Village & 2,810 & 5,620 & 67,440 \\
National Estimate for & & & $24,413,280$ \\
All 362 Villages & & & \\
\hline
\end{tabular}

openings, and, less frequently, reburials. Pastors may also preach in other parishes, and on these occasions, the parish that extends the invitation gives cash and food to signal their appreciation and generosity. Pastors also accompany choirs and sports teams who perform beyond the village. When these groups are given presents or win prizes, part of the gift or prize is routinely given to pastors who accompany them. While pastors do not actively solicit these gifts, giving to officiating pastors on these occasions is a well-established practice. Pastors cannot easily refuse these gifts without offending the would-be givers by implying that they cannot afford to make such a present.

Although people discuss these gifts in daily conversation, it is difficult to establish their value over a twelve-month period for several reasons: (I) these gifts form part of a pastor's personal income and do not routinely pass through church accounts; (2) pastors in populous villages will perform more of these services than those in smaller villages; (3) gifts typically also include noncash elements, which are more difficult to assign value to ${ }^{19}(4)$ wealthier villages can afford to be more generous to their pastors than less prosperous villages can; (5) more of these gifts are given at certain times of the year (for instance, at Christmas, returning migrants often make additional gifts); and (6) since remittances are often used to provide these gifts, families with more expatriate members can afford to be more generous than those with fewer members abroad. Despite these difficulties, we thought it important to make at least a very conservative estimate based on detailed information from two villages on the size and frequency of various casual gifts.

To do this, we took figures from our four representative villages and 
Table 4. Estimated Median Value of Casual Gifts to Pastors for Religious Services (SAT)

\begin{tabular}{lccc}
\hline Contribution Type & Fortnightly & Monthly & Annually \\
\hline Wedding & 100 & 200 & 2,400 \\
Baptism & 50 & 100 & 1,200 \\
Funeral & 100 & 200 & 2,400 \\
Visiting Ministry & & $100^{*}$ & 1,200 \\
Blessings & 50 & 100 & 1,200 \\
Secular Services & & $100 \dagger$ & 1,200 \\
Total per Village & & & 9,600 \\
Total (362 Villages) & & & $3,475,200$ \\
\hline
\end{tabular}

* It would be unusual for pastors to preach in other villages more than once a month.

† It would be unusual for village pastors to perform more than one meeting opening per month, but pastors in the town area may be called on more often to perform ceremonies for government and commercial entities.

generated figures for each of the categories of casual gifts mentioned earlier. To avoid overestimating these values, we used figures from the lower end of the range for each. For instance, pastors were given gifts of between SATIOO and SAT2,000 for performing weddings, but we used the midrange figure as the basis for our calculation. The frequency with which services are performed influences the estimate. Pastors in small villages, for instance, may perform one wedding per month, while those in larger villages may perform weddings weekly. We used figures from mid-size villages to avoid overestimating the frequency with which these services were performed. This estimate is presented in table 4 .

Annual Gifts: The Fa'amati and the Mē

Congregations also make a series of offerings (taulaga) as part of an annual cycle of religious giving. The first annual collection is the $\mathrm{Fa}^{\prime}$ amati, in which church districts designate an item or home improvement that each congregation is to provide for its pastor and his fam- 
ily. ${ }^{20}$ While minimum values are not set, competition between villages to demonstrate to one another the depth of their commitment ensures that congregations typically exceed the basic requirement. For instance, in 20I0, thirteen Congregationalist villages in Faleata were asked to provide vehicles for their pastors' use. The values of the vehicles purchased ranged from SAT76,950 to SATI 45,000. All were new, luxury cars and cost significantly more than either entry-level or secondhand vehicles, which were also readily available. The value of each village's vehicle was known within the district.

The difficulty with calculating the value of the Fa'amati is that, in any given year, the nature of the specified improvement, and hence its cost, may vary considerably from district to district. Thus, in 2005, congregations in one district purchased bedroom furniture, while those in another bought vehicles for their pastors. In that year, one of the villages in the district purchasing furniture raised SAT25,500, while the adjoining village in a different district—one buying cars—raised SAT93,000. Estimating the value of the Fa'amati is further complicated by the fact that amounts collected in any village also vary from year to year. For example, a village that raised SAT2 5,500 for its $\mathrm{Fa}^{\prime}$ amati one year raised SAT 5 I,OOO the following year. Calculation of a reliable figure for this element would require an average of these costs over, say, five years. Without adequate data to calculate a long-term average, we used a median figure for four representative villages in the same year to arrive at a Fa'amati contribution of SAT3 5,000 .

The second of the annual gifts, the $M \bar{e}$, is a collection for the work of the national church. ${ }^{21}$ In the Congregational Church, the $M \bar{e}$ includes an offering for church development in Sāmoa (taulaga mo Sāmoa), which funds overhead costs and capital expenditure such as building construction. ${ }^{22}$ The $M \bar{e}$ also includes an offering for church missionary work abroad (taulaga o nu'u ese); an offering for the religious work of senior members of congregations who support the activities in the village (taulaga o le 'autaumafai); and an offering for the work of those who support the churches' work through prayer (taulaga o le 'auleoleo). ${ }^{23}$ In the Methodist Church, the $M \bar{e}$ comprises the major offering (taulaga ole faiga $M \bar{e}$ ) and smaller contributions to a ministers' retirement fund (taulaga faife 'au malolo); Sāmoa's National Council of Churches (taulaga o pepa talosaga); the Pacific Council of Churches (taulaga ole PCC); a Bible fund (taulaga ole Tusi Paia); a fund for Sunday School and youth work (taulaga aso sa 
tupualaga talavou); a fund for church missionary work (taulaga o nu'u ese); and the Methodist Church newspaper, Fetuao.

To meet goals, "suggested" amounts for each of the collections are set for babies, children, adults, and seniors, which, as with the regular maintenance contributions, become, in effect, the minimum amounts. Some villages further refine this schedule, distinguishing between different types of matai and setting different amounts for orators (tuläfale) and high chiefs (ali $i$ i), respectively, which also become minima. For example, in some villages, the suggested figures in the November 20 Io taulaga mo Sämoa were SAT500 for tuläfale and SATI,000 for ali ‘i. Villages' previous year's contribution levels for each of the collections become de facto benchmarks for the current year. Villages within a district typically compete with one another to demonstrate their religious commitment through cash giving, which ensures that suggested amounts are routinely exceeded and that annual totals tend to rise steadily.

Data on $M \bar{e}$ contributions from a sample of fifty-one Methodist congregations in three districts were used to generate table 5. The data show the variation within these gifts and the challenges of calculating an average figure. The average $M \bar{e}$ figure for sampled villages, at SAT46,2 I5.93, is significantly higher than the median figure of SAT39,III.79, and both of these figures mask the very considerable ranges within districts.

To calculate a national estimate of the annual value of $M \bar{e}$ contributions, we multiplied the average of the three districts' medians (SAT39, I I I.79) by the number of villages (362) to reach an estimate of SATI $4, \mathrm{I} 58,467.98$.

Table 5. 2009 Mè Contributions (sAT)

\begin{tabular}{lrrrr}
\hline $\begin{array}{l}\text { Village } \\
\text { Contributions }\end{array}$ & District 1 & District 2 & District 3 & $\begin{array}{c}\text { Three Districts } \\
\text { Average }\end{array}$ \\
\hline Minimum & $19,516.30$ & $8,770.60$ & $10,018.20$ & $12,768.37$ \\
Maximum & $273,259.35$ & $79,716.15$ & $105,778.78$ & $152,918.09$ \\
Range & $253,743.05$ & $70,945.55$ & $95,760.58$ & $140,149.73$ \\
Average & $56,377.90$ & $28,004.54$ & $54,265.34$ & $46,215.93$ \\
Median & $40,716.62$ & $22,236.15$ & $54,382.60$ & $39,111.79$ \\
Total & $1,353,069.60$ & $560,090.73$ & $325,592.04$ & $746,250.79$ \\
\hline
\end{tabular}




\section{Occasional Extraordinary Expenditures}

for Construction

Congregations will, from time to time, build or rebuild church buildings, pastors' homes, and ancillary buildings. Building projects involve significant cash contributions and, in many cases, labor contributions from villagers. These extraordinary projects occur on a longer cycle than either of the regular contributions outlined above. These can be calculated only approximately because, while the costs of projects are easily enough established, villages do not rebuild these structures on a regular schedule. One village may rebuild its church or its pastor's residence after damage from a hurricane. Its activity may lead villages around it to reconsider the adequacy of their own church facilities and may encourage them to extend or rebuild an existing building.

The sums invested in these projects will vary considerably for obvious reasons. For instance, the cccs congregation at Alafua, which has twentythree member families, built a new church in September 2004 at a cost of SAT44I,959, some twenty-four years after building their first church (Vatau and Alapati 2004). Established churches in larger villages, with significant expatriate populations, have built churches valued at over SAT5 million. Calculating the value of this occasional capital expenditure presents unique problems because these are related to villages' factor endowments and to the nature of their engagement with local and international economies. While this expenditure may be significant, we have insufficient data at this time to make an estimate of the value of this form of support. ${ }^{24}$

\section{Personal Gifts}

During a pastor's service, a congregation may choose to support the costs of sabbatical and long-service leaves, ${ }^{25}$ medical treatment, ${ }^{26}$ and his children's weddings and graduation ceremonies. To express their gratitude, congregations may also provide retirement gifts to long-serving and respected pastors. Gifts documented included cash, vehicles, land, houses, overseas travel, and, in some cases, several of these. The value of these gifts will vary with the length of service, the stage of the pastor's family cycle, and the nature of the relationship between the pastor and his congregation. Again, while this type of expenditure may be significant, we have insufficient data to make an estimate of its value. ${ }^{27}$ 


\section{An Estimate of the Total Value of Contributions}

A total estimate was constructed by adding together our estimates of the value of regular maintenance contributions, casual gifts, and annual gifts. This figure was then multiplied by the number of villages in Sāmoa (362). The data are summarized in table 6.

The value of contributions to mainstream denominations is then, at the very least, SAT 54,7I 7,024 per annum, or SATI,052,250 per week.

These estimates are, we believe, very conservative. They assume that each village has a single congregation, but, in fact, numerous villages have several mainstream denominations and contribute significantly more than is assumed in this article. In villages with several mainstream churches, in addition to the competitive pressures within congregations there is also often competition between denominations. Also, the estimates omit significant categories of expenditure that are routinely met by congregations but that, for reasons set out earlier, are difficult to calculate reliably. For instance, they do not include the periodic costs of replacing church buildings and pastors' accommodations and vehicles, of celebrating pastors'

Table 6. Estimated Median Value of Contributions to Mainstream Churches (SAT)

\begin{tabular}{lcrr}
\hline Category & Fortnightly & Monthly & Annually \\
\hline Maintenance & & & \\
$\quad$ Offertory & 2,500 & 5,000 & 60,000 \\
$\quad$ Expenses & 150 & 300 & 3,600 \\
$\quad$ Labor & 160 & 320 & 3,840 \\
Casual Gifts & & 800 & 9,600 \\
Annual Gifts & & & 35,000 \\
$\quad$ Fa'amati & $\mathrm{n} / \mathrm{a}$ & $\mathrm{n} / \mathrm{a}$ & 39,112 \\
$\quad$ Mé & $\mathrm{n} / \mathrm{a}$ & $\mathrm{n} / \mathrm{a}$ & 151,152 \\
Total per Village & & & $54,717,024$ \\
Total (362 Villages) & & & \\
\hline
\end{tabular}


Table 7. Annual Church Contributions in National Context: Some Comparisons

\begin{tabular}{lcc}
\hline Category & $\begin{array}{c}\text { 2005 Value } \\
\text { (sAT Millions) }\end{array}$ & $\begin{array}{c}\text { Contributions as } \\
\text { Percentage of } \\
\text { Revenue or } \\
\text { Expenditure }\end{array}$ \\
\hline Total Government Receipts & 329.59 & 16.60 \\
Government Tax Revenue & 171.86 & 31.84 \\
Government Guarantees Issued & 81.06 & 67.50 \\
Foreign Debt Servicing & 17.16 & 317.60 \\
Capital Obligations to International & 47.89 & 114.26 \\
$\quad$ Financial Institutions & 36.50 & 149.91 \\
Exports & 39.60 & 138.17 \\
Government Expenditure Health & 52.41 & 104.40 \\
Government Expenditure Education & 11.14 & 491.18 \\
Government Expenditure Agriculture & 7.30 & 749.55 \\
Government Expenditure Women & & \\
$\quad$ Community and Social Development & 36.98 & 147.96 \\
Total Statutory Expenditure & & \\
\hline
\end{tabular}

Source for 2005 values: Finance Ministry 2006b.

children's weddings, and of providing retirement gifts and allowances that may be paid by some congregations but not others. ${ }^{28}$ They do not include contributions made by members of tithing churches, which now make up some I 6 percent of Sāmoa's church membership. The real value of contributions made to all churches is clearly significantly higher than our estimate, ${ }^{29}$ which is intended only to provide a basic figure to allow us to place this cost in the context of the national economy. When these contributions are expressed as percentages of components of the national economy for the year 2005 , as in table 7 , the churches' economic significance becomes more obvious.

\section{Local Impact of Contributions to Churches}

The leaders of local congregations determine the division of church contributions between the funds retained for the personal use of pastors and 
those sent to the national church to fund national and international programs. Some money given to the national church is returned to the village in the form of subsidies to village children who are educated in church schools and in the form of religious instructional material. But, ironically, some national churches also lend money collected from individuals and parishes back to them, with interest, to allow them to fund church development. The Sämoa National Human Development Report noted that "the CCCs has tried to help parish members through a loan scheme from which they could borrow money for the construction and/or maintenance of their church halls, pastor's residence and so forth." Parish members can "apply for assistance at a small interest [rate] of 5 per cent per annum to finance local parish youth halls, pastor's residence and so forth" (Kolia 2006, 38-4I, I39).

Money given to pastors is effectively removed from the village economy because pastors cannot serve in villages to which they "belong," and they have no personal property in the village in which to invest money. Apart from payments of the pastor's children's school fees and for goods purchased in the village, contributions are expended beyond the village on such things as purchase of freehold land, homes, appliances, overseas education for children, overseas travel, and occasionally even businesses. Even Fa'amati contributions, which seem to represent an investment in village-owned capital assets such as the pastor's home and fittings, do not always remain in the village. While the pastor's house remains the property of the village, pastors often remove furniture and fittings accumulated during their service when they leave a village.

The cash and labor extracted fortnightly from a congregation's families (matäfale) are technically "surpluses" - that is, money remaining after families' basic living costs have been met. In practice, this is not so. Kerslake's study revealed that in many families, the church contribution has first call on family income, and other costs are allocated after this has been set aside. Kerslake noted that "interviews over household spending showed that most of the money earned or remitted is given to the church as family contributions. School fees, food for the family, electricity bills, and other expenses were secondary to church donations." Church contributions were the most frequently mentioned expenses, and "matai, or family chiefs, stated that there was always a shortage of money because of their obligations to the church and to family activities" (Kerslake 2004, $30,25-26,24)$. Furthermore, when families' available income is inadequate to reach historically acceptable contribution levels, individuals may 
be forced to borrow from other family members or friends, or to divert remittances from abroad from the purposes for which they were originally intended - such as the payment of school fees and the purchase of school uniforms and medical treatment-in order to make up shortfalls.

If families were free, and chose, to accumulate the resources they contribute to the church, the resulting savings could be used as evidence of savings history to leverage loans, as collateral for loans, as capital to invest in new enterprises, as working capital for existing enterprises, or as investment in social capital creation through such things as education. Where church contributions are not truly "surplus" funds, giving works against the government's stated goal of "responding to village and community needs" by "developing village income-generating enterprises" (Salele 2006, I IO). Labor contributed by families to the pastor's household has a similar consequence: employed in their own projects, or in social capital creation, it could reduce wage costs and generate increased outputs, profitability, and other, noneconomic benefits.

If families were free, and chose, to invest these resources in children's education, the families', and the village's, stock of social capital could be increased both by increasing rates of participation and by improving infrastructure and instructional services that villages subsidize. As Gatoloaifaaana Tilianamua Afamasaga noted, some ro percent of 56,992 children aged 5 to $\mathrm{I} 7$ enumerated in the $200 \mathrm{I}$ census were not enrolled in primary or secondary school. If the net enrollment figure, that is, those actually in school, is used, this percentage is higher; the net enrollment rate in primary education in 2004 was 67 percent, significantly less than the gross enrollment rate of 97 percent, and has been declining since 1995 (Afamasaga 2006, 84). The issue is more serious in secondary school, where transition rates show students leaving at all levels. These trends led Afamasaga to comment that "the current situation raises questions of why these children are not at school and where they are. To address the issues requires government and all communities to find out and create appropriate strategies to enable all children in Sāmoa to be educated. Children who do not attend school are potentially wasted human resources" (2006, 85).

Part of this phenomenon has been traced to the organization of education and part to the availability of resources. The Sämoa National Human Development Report noted, "There is a real sense of hardship among people particularly in the rural areas who find it difficult to keep their children in school either due to inability to pay fees or to contribute in kind to the upkeep of schools" (So'o, Va'a, and Latofanoa 2006, 32). This pattern 
has a longer-term consequence because those who are least able to invest in education are those who are already living in poverty, currently estimated to be around 20 percent of the population (SBS 2002). Those most affected by hardship were landless families or individuals, unemployed youth and parents; single income households; families with many children to look after; and people who live in isolated villages with poor transport (Muagututi'a 2006, 62). The most serious long-term consequence is that low-income families, drawn into competitive giving within villages, continue to give more to the Church to match the donations of wealthier families and, in the process, deny their children access to the education that could increase their opportunities in the mid-term.

There is, of course, an alternative, which is to withdraw, partially or completely, from this cycle of competitive giving, and this is happening already. Kolia noted that "people are slipping away or are no longer going to church because of the huge loans from the National Provident Fund (NPF) or the Development Bank of Samoa (DBS). Church financial and other material demands on church members who are already experiencing economic difficulties are a recipe for church desertion. As expected, the general church belief is that in the end everyone is accountable to the Creator and Sustainer of life and therefore will be punished accordingly" (2006, I38). In small communities, where most accept the disciplines of church membership and its financial consequences, it is not surprising that those who exempt themselves invite the very public opprobrium of their community. Withdrawal may carry a considerable social cost within the family, church, and the village, and may require considerable determination and indifference to public opinion. Furthermore, the pressure is felt not only by the dissenter but also by immediate kin and members of the extended family who are collectively associated with the deviance. They may be denied social acknowledgement and support within the village and become the butt of public criticism and humor. Even determination in the face of such social pressure may be insufficient: families and villages have a range of economic sanctions that may eventually force compliance. In some cases, those who withdraw are denied economic support and, more crucially, access to customary land by their families in an attempt to secure their conformity with established giving norms (see Thornton, Kerslake, and Binns 2010). Some who have attempted to withdraw report having been subjected to considerable pressure from their family, church, and village leaders, all of whom have a vested interest in maintaining the appearance of solidarity on this issue, since all are indirect beneficiaries of the cur- 
rent system. ${ }^{30}$ Their reputation as leaders depends on their ability to secure compliance with norms that they are elected to represent and enforce.

\section{National Impact of Contributions to the Churches}

The first impact of church contributions is the direct cost in foregone revenue to the government. Neither pastors' incomes nor their fringe benefits are taxed by the government. If a pastor making SAT50,000 per annum were to pay personal income tax at standard tax rates, he would contribute SATIO,200 annually, and if 362 pastors paid taxes at this rate, the government would derive at least $\mathrm{SAT}_{3}, 692,000$ in taxation revenue annually. This figure would increase significantly if, say, SAT I0, 000 of each pastor's fringe benefits were also to be taxed. Revenues that the government foregoes by choosing not to tax pastors' incomes and benefits must then be financed through interest-bearing borrowings or loans in local and international capital markets.

Sāmoa has two social security provision schemes. The first is the Samoan National Provident Fund, to which employees make a statutory minimum contribution of 5 percent of gross wages, which employers match. If 362 pastors and their "employers" were responsible for paying this tax on an income of SAT 50,000 per pastor, the government would receive an additional SATI.8I million. This sum could, in NPF hands, increase the pool of funds available for the funding of small enterprises that depend on microcredit from the provident fund. The second social security provision scheme is the Samoa Accident Compensation Board, which requires each of the nation's employers to pay a statutory I percent payroll tax. If this tax were paid on each pastor's income, an additional SATI 8 I,, 00 would be available to the government. On the basis of the above calculations, the foregone revenue from these levies would total SATI,99I,000.

It is, therefore, not surprising that the Asian Development Bank has been looking at the status of pastors' income, which uses up the bulk of the contributions to the churches, and has noted, "With respect to the tax-free status of ministers of religion, it is not unreasonable for the community to expect that all residents should make a reasonable and equitable contribution to government services. Changing the tax status of ministers of religion would probably meet widespread community resistance, however, and effective consultation with the community would clearly be needed before changes were made. However, the key point is that such matters should be made transparent to the general public so that effective 
consideration can be given to an appropriate policy" (ADB I999, Xvi). While Sāmoa has moved, and is moving, to reform its tax system and to remove anomalies in the treatment of different groups of taxpayers, this restructuring appears to be focused on complying with requirements of World Trade Organization membership and of various free trade agreements (Finance Ministry 2005b, 2008). It therefore looks unlikely that the government will alter the tax treatment of clergy income.

These figures are of course offset against economic activity generated by church construction programs, which the National Accounts of Samoa routinely identify as significant in their commentary on the construction sector (Finance Ministry 2005a). It is also true that where commercial construction companies are engaged to build church facilities, their employees will pay income tax, payroll tax, and accident insurance premiums, and the building supply companies will pay company taxes on their profits and duties on imported building materials and equipment. However, this sum seems likely to be comparatively small: the entire construction sector generated an annual average of 7.8 percent of the gross domestic product between 2002 and 2006 (Finance Ministry 2006a), even when significant hotel construction and physical infrastructure projects were underway.

The second cost to government comes from foregone productivity. The commitment to make contributions to the church may prevent families from investing in their children's formal education and constrains the formation of social capital associated with economic growth. The 2006 Samoa National Human Development Report noted with concern the declining rates of participation in formal education and the increasing unrealized social capital. In the future, both local and global labor markets will require better-educated employees. The denial of educational opportunities to the children of low-income families, who have to choose between meeting church contributions and paying school and university fees, will effectively exclude individuals from participation in better-paid sectors of the labor market and limit their opportunities for social and economic mobility. But low levels of social capital could also make the nation less attractive as a location for establishment of global business operations and deny it the income that would be available from more active participation in the higher-value areas of global commerce. Participation in relatively low-skill, low-value activities such as assembly, which can be automated, will not produce the higher incomes that can be earned through higher-skill, higher-value activities such as working in call centers and providing back-office functions for commercial activities. 


\section{The Future}

Whether or not Samoans continue to contribute cash, labor, and services to their churches at current levels will depend on the mainstream churches' ability to maintain giving at these levels as a social "norm." On the surface at least this seems highly likely. While Kerslake's 2004 study revealed some disillusion with giving to the church, there was also clear support. This is not surprising, as the mainstream churches are thoroughly integrated into village social organization and play a powerful role in village polities. The close alliance between church and village leadership structures ensures that mainstream churches' interests are reflected in village political activity. It is thus not simply the church or church personnel who set and maintain levels of giving, but also secular leaders whose influence extends into village families.

Could growing secular resistance to the demands of the church undermine Samoans' generosity? Again, this seems unlikely. Kerslake revealed that while pastors may place moral pressure on parishioners from the pulpit to be generous, the aspirations of the pastor and the church are "enforced" by people who hold power both as deacons in the church and as matai or family heads in the secular realm. Their ability to encourage families to contribute generously is, in part, a reflection of their ability as secular leaders (Kerslake 2004). In these circumstances, it is unlikely that a church-village split, in which secular leaders might align themselves against the church and articulate a contrary position, will emerge.

However, until relatively recently these church-village alliances have not faced serious and direct competition from other denominations. The only alternative for those disaffected with church practice was to leave the church-which was, for most people, unthinkable and was, in many villages, simply not permitted. The establishment of new evangelical churches, particularly around Apia, and access to a range of media-born models of religious practice, have given Samoans a range of new models of religious practice and governance to consider. These "new" churches, which are now growing rapidly, have been critical of some mainstream churches' practices, including giving practices, which they contend enrich pastors while impoverishing families and preventing them from achieving personal goals. Recent research shows that the Latter-day Saints and Assemblies of God are growing rapidly and are drawing many of their new converts from low-income families; they attribute their growth to 
relatively low costs of membership and various educational and other benefits (Goman 2006; Thornton, Kerslake, and Binns 2010, I0-I2).

These external influences represent a threat to the dominance of mainstream churches and to their capacity to maintain a particular model of practice as normative. While these alternatives were confined largely to Apia, they did not represent an immediate threat, but as migrants and new converts embarked on "missionary activity" in their villages, they posed a more direct challenge to the church-village alliance. This concern was reflected in some villages' resistance to the attempts of "new" churches to establish a presence in villages through a series of banishments of those who promoted new faiths. Some contend that this response stems from established churches' fear that "new" churches will erode their membership and the economic and political power that they currently enjoy (Schaer 2002).

Supporters of the mainstream churches, including the Reverend Oka Fau'olo, chair of the National Council of Churches (which comprises the three major churches and a small number of others), dismiss that argument. They insist that their motive for opposing new churches stems from the unwelcome disruption and disharmony that their establishment causes within villages (Schaer 2002). Indeed, support for banning new churches in some villages occurs because the village councils zealously guard their authority to control events within village boundaries and throw their weight behind the mainstream churches because these incursions challenge not only the churches but also the councils' authority.

However, the recent concern may also have arisen because, in the past, the "new" churches tended to avoid confrontation with established village churches. As Reverend Fau'olo contended, returning migrants have shown themselves more willing to confront the issue (Schaer 2002). Leaders of the "new" churches have been taking cases to the Lands and Titles Court and the Supreme Court, and have been winning judgments that confirm the constitutional right to freedom of worship, as well as appeals against banning orders issued by village councils against members of dissenting religious groups. In response, the National Council of Churches has canvassed amendments to the constitutional guarantee of religious freedom, and has asked the prime minister to review and approve only "new" churches that do not threaten the harmony of Samoan society.

The established churches recently won some support for their attempts to curb introduction and expansion of new denominations. In 20I0, the churches persuaded the Samoan government to establish a Commission 
of Enquiry into Religious Freedom. In a statement issued at the time, the government said its concern arose from the fact that freedom of religion has posed a direct challenge to the autonomy of village councils. The general secretary of the National Council of Churches, the Reverend Maauga Motu, said in a radio interview: "It is a good move to stop more religions from coming into the country, as there are enough already. Part of the church is already fed up with this many religious beliefs coming into the country and disturbing or doing this moving of people round to religions, from one religion to another religion. The proposal by the government is a correct move and it's about time to stop it now" (Radio New Zealand International, I6 March 2010).

It will be interesting to see whether or not they succeed. The provisions for religious freedom are embodied in the Samoan constitution and in the various international human rights conventions to which Sāmoa is signatory. The Samoan government may come under significant international pressure if it attempts to withdraw rights that are embodied in either the constitution or in the UN Declaration of Human Rights, to which it is a signatory.

Finally, significant sanction for compliance to the norms of giving rests on a family's right to deny access to communal land to members, and a village's right to impose sanctions, including banishment, on individuals and groups who choose to deviate from established patterns of conduct. These factors have ensured that most people comply with established patterns if only because they have no realistic alternative. But the subdivision and sale of increasing amounts of government land around Apia and the subdivision of some privately owned freehold land have made more freehold land available for those who wish to live beyond the reaches of village control. Remittances from migrants, along with the development of an active public land market and of commercial lending facilities, have made the possibility of living a more "privatized" lifestyle in the suburbs developing around Apia both more realistic and more attractive. Some combination of these factors may lie behind the rapid growth and increasing popularity of these areas.

\section{Conclusion}

Established churches may have increasing difficulty controlling the terms of engagement between Samoans and their religion. While the alliance 
between church and village may remain intact in the meantime, it is likely that church-government relations will not be without tension as the government and courts, committed to the enforcement of human rights embodied in the constitution, will inevitably hand down decisions that weaken the mainstream churches' influence on the norms of Samoan religious practice. If this leads to the establishment of new congregations and new religious practices in villages, it may well be that new norms for giving will become established in time. Where people are able to demonstrate their religious commitment in denominations that do not demand a significant part of their income, this change may occur rapidly. In fact, this may lie behind the recent and steadily increasing growth of the tithing churches, which offer not only spiritual comfort but also opportunities for subsidized education in Sāmoa and abroad.

A final issue, which may have a profound effect on current giving practices, will be future levels of migrant remittances. Since these are, according to Kerslake's study, a major source of church contributions, any decline in remittance levels may reduce people's capacity to continue to contribute at current levels, even if it does not replace their disposition to do so. Several factors could lead to declines, including economic restructuring and the state of labor markets in migrant enclaves in New Zealand, Australia, the United States, and American Sāmoa, which could constrain the amount of discretionary income to which migrants have access and are able to remit. The recent contractions in the global economy have had profound effects both on the availability of employment and on wage and salary growth in all of the migrant enclaves. This has been exacerbated recently by the severe contraction of the tuna processing industry in American Sāmoa, which has historically employed large numbers of migrants from Sāmoa. Another factor is the possibility of "remittance decay," a declining disposition on the part of overseas-born Samoans to remit as their ties with their parents' and grandparents' homelands become attenuated over time. There is emerging evidence of this in several longitudinal studies currently being conducted in New Zealand and in Australia ( $\mathrm{Va}^{\prime} \mathrm{a}$ 200I).

Declining remittance levels occurring alongside an increasing cost of living may force people to re-prioritize their expenditures on church-related activity and may prove the catalysts for the transfer of allegiance from the mainstream churches to denominations offering alternative forms of participation that are less expensive alongside a similar range of spiritual and material benefits. 


\section{Notes}

I This statement appeared first in the bilingual document, Strategy for Development of Samoa: Opportunities for All (Treasury Department 2002), and in a series of Samoan government strategic plans since then. The Samoan translation of the text is, in each case, rather more declaratory than this English rendering.

2 This article makes no comment on the impact of these contributions on the lives and opportunities of expatriate Samoans who subsidize these gifts with income earned abroad. Indeed, as noted by Mirna Carrillo (2006), some Samoans migrate for the express purpose of serving their families' financial needs and do so willingly and at considerable personal cost.

3 Women's, untitled men's, and youth groups all have access to labor that could be employed in revenue-generating activity. The potential for corporate activity in the village is evident from the success of Women in Business, which has provided microfinancing for women who are then able to generate regular income from activities such as fine mat weaving, coconut oil processing, and honey production.

4 The Small Business Development Fund makes small commercial loans. The National Provident Fund of Samoa makes small loans to its policyholders.

5 The Congregational Christian Church in Samoa is formally known as the Ekalesia Fa'apotopotoga Kerisiano Samoa (EFKS) and colloquially as the LMS or Lotu Ta'iti. The Methodist Church of Samoa is known as the Lotu Metotisi or Lotu Toga. The Roman Catholic Church is known in Sāmoa as the Lotu Katoliko or Lotu Pope.

6 The studies by Samoan economists include Fairbairn I985, I99I; Fairbairn and others I99I; and Fairbairn Pacific Consultants and Kolone Va'ai and Associates 1994 .

7 Unfortunately, the published data do not disaggregate the church and customary expenditure categories.

8 The Samoan tāla (SAT) is currently valued at NZ\$0.56, A \$०.5०, and us\$o.35, and apart from minor fluctuations has retained these equivalencies over time.

9 For freewill offerings, the Congregational church uses the term alofa and the Methodists use peleti.

Io These sums may be increasing. Villages formerly engaged a tufuga or specialist builder to direct the project and provided unskilled labor for the project. Congregations are increasingly hiring construction companies on a commercial basis.

I I Tusigaigoa is system of pledges made by all whose names are known in the village census. This usually comprises a "recommended" per capita sum for working adults, non-working adults, and children, which becomes a de facto minimum sum. 
I2 Village labor is still used at certain times in building projects but its value is very difficult to quantify, as our attempts to estimate the value of local labor employed in two projects proved.

I 3 We plan to attempt to calculate an amount for the tithing denominations using data from the 2008 census.

I4 Mainstream Samoan churches have not yet embraced women clergy, and, judging from discussions at their annual conferences, seem unlikely to do so in the near future.

I 5 Previous years' amounts become benchmarks and are used in setting annual goals. Figures may vary with family movements within villages and increases in numbers of expatriate villagers. Figures may also decline where families reduce their contributions to draw attention to unresolved tensions between the pastor and the parish in the most public way available to them.

I 6 Factor endowments are "natural" factors that influence wealth available from local primary production: availability and contour of land, natural water, soil types, access to fisheries, productivity of fisheries and forests, etc.

I7 As this project continues, we will collect a larger data set and refine this measure.

I 8 The value assigned to volunteer labor is based on the average hourly wage at the Yazaki EDs (Sāmoa) plant, which is Sāmoa's largest private employer.

I9 While it is fairly simple to calculate the value of tinned meat and fish gifts, it is more difficult to establish values for fine mats ('ie toga), bark cloth (siapo), and bolts of cloth that are given on these occasions because quality cannot be readily established.

20 Over time, Fa'amati has become the proper name of the activity around this collection, which used to be held in the month of March (Mati).

2I This collection is also named after the month in which it was traditionally held, May $(M \bar{e})$.

22 The Congregational Church, for instance, recently completed construction of a new SAT 5 million multipurpose building at the Malua Theological College, which has offices for the church's chairman, vice chairman, treasurer, and secretary and can accommodate I,200 people for church conferences and meetings. The Samoa Observer reported, "The church secretary Reverend Paulo Koria said the hall is basically for the church's big annual conference which runs for two weeks in May" (Samoa Observer online, 30 November 2004).

23 The offering for those who support the church's work through prayer is known in the Methodist Church as the fono tatalo and in the Congregational Church as the mafutaga tatalo.

24 We plan to develop an estimate for this component of expenditure based on the numbers of churches built or rebuilt in a given year.

25 The cost of such leaves often includes overseas travel. 
26 One congregation met the recurrent costs of flying its pastor to and from American Sāmoa for regular dialysis.

27 We plan to develop an estimate based on the range of values of gifts of this type.

28 In a rural district in 200I, one village replaced its pastor's accommodation at a cost of SAT $8 \mathrm{I}, 000$, and another replaced its church building at a cost of SAT 200,000.

29 If, for instance, I percent of the villages replaced their churches annually at a cost of SAT333,000, this figure would rise by SATI.09 million; if I percent of the villages replaced their pastors' accommodation at SAT 80,000 , this figure would rise by a further SAT264,000.

30 This social pressure may lie behind the urban drift, as people seek to remove themselves from the village and its control. The urban drift, in turn, contributes to shrinkage in the size of the village population and economy, and losses of both physical and social capital.

\section{References}

ADB, Asian Development Bank

I999 Country Assistance Plan (2000-2002) Samoa. Manila: Asian Development Bank.

Afamasaga, Gatoloaifaaana Tilianamua

2006 The Challenge in Education. In So`o, Va'a, and Lafotanoa 2006, 8 I-IOO.

Brown, Richard P C, and Dennis A Ahlburg

I999 Remittances in the South Pacific. International Journal of Social Economics 26 (I-3): 325-334.

Carrillo, Mirna

2006 Malo le Folauga Brain Drain: A New Perspective. ISP [Independent Study Project] Collection, paper 306. Brattleboro, vT: SIT Study Abroad. Available online at http://digitalcollections.sit.edu/isp_collection/306 [accessed I 7 January 20II]

Economic Development Department, Government of Western Samoa

I973 Western Samoa: Review of the Economy 1972. Apia: Department of Economic Development.

Fairbairn Pacific Consultants and Kolone Va'ai and Associates

1994 The Western Samoan Economy: Paving the Way for Sustainable Growth and Stability. Canberra, АСт: Australian International Development Assistance Bureau.

Fairbairn, Te'o I J

I 985 Island Economies: Studies from the South Pacific. Suva: Institute of Pacific Studies, The University of the South Pacific. 
I99I The Western Samoan Economy: Prospects for Recovery and Longterm Growth. Canberra, АСТ: Australian International Development Assistance Bureau.

Fairbairn, Te'o I J, Charles E Morrison, Richard W Baker, and Sheree A Groves

I99I The Pacific Islands: Politics, Economics, and International Relations. Honolulu: East-West Center International Relations Program.

Finance Ministry, Government of Samoa

2005a Gross Domestic Product Report 2005. Apia: Ministry of Finance, Government of Samoa. Available online at http://www.mof.gov.ws/Services/ Economy/NationalAccountReports/tabid/56 I 9/language/en-US/ Default.aspx [accessed I 5 January 20I I]

2005b Strategy for the Development of Samoa (SDS) 2005-2007: Enhancing People's Choices. Apia: Economic and Planning Division, Ministry of Finance, Government of Samoa. Available online at http://www.mof .gov.ws/Services/Economy/EconomicPlanning/tabid/56 I 8/language/ en-US/Default.aspx [accessed I 5 January 20I I]

2006a Gross Domestic Product Report 2006. Apia: Ministry of Finance, Government of Samoa. Available online at http:/www.mof.gov.ws/ Services/Economy/NationalAccountReports/tabid/56 I 9/language/ en-US/Default.aspx

2006b Public Accounts for Financial Year Ended 30 June 2006. Apia: Ministry of Finance, Government of Samoa. Available online at http://www .mof.gov.ws/Portals/I 9 5/Publications/Economy/PUBLIC\% 20 ACCOUNTS\% 202005-2006.pdf [accessed I 5 January 20I I]

2008 Strategy for the Development of Samoa (SDS) 2008-20I2: Ensuring Sustainable Economic and Social Progress. Apia: Economic and Planning Division, Ministry of Finance, Government of Samoa. Samoan and English versions available online at http://www.mof.gov.ws/Services/ Economy/EconomicPlanning/tabid/56r 8/language/en-US/Default.aspx [accessed I 5 January 20II]

Goman, Jessica

2006 Mormonism in Samoa: Cultural Dialogues. ISP collection, paper 337. Brattleboro, VT: SIT Study Abroad. Available online at http:// digitalcollections.sit.edu/isp_collection/337/ [accessed I 7 January 20I I]

Kerslake, Maria Talaitupu

2004 Aspects which Contribute to the Creation of Wealth and Poverty within the Family Setting. Apia: Report to National University of Sāmoa Research Committee.

Kolia, Fepa'i Fiu

2006 The Church and Development. In So'o, Va'a, and Lafotanoa 2006, I $37-$ I 48 . 
Lockwood, Brian

I97 I Samoan Village Economy. Melbourne: Oxford University Press.

Macpherson, Cluny

I992 Economic and Political Restructuring and the Sustainability of Migrant Remittances: The Case of Western Samoa. The Contemporary Pacific 4:IOO-I35.

Macpherson, Cluny, and La'avasa Macpherson

2009 The Warm Winds of Change: Globalisation in Contemporary Samoa. Auckland: Auckland University Press.

Muagututi'a, Sefuiva Reupena

2006 The Human Development Indices. In So‘o, Va‘a, and Lafotanoa 2006, 47-68.

Pitt, David C

I970 Tradition and Economic Progress in Samoa: A Case Study of the Role of Traditional Social Institutions in Economic Development in Western Samoa. Oxford: The Clarendon Press.

Salele, Fa'amoetauloa Wood

2006 Economic Update. In So‘o, Va'a, and Lafotanoa 2006, IOI-I I 2.

SBs, Samoa Bureau of Statistics

I997 Household Income and Expenditure Survey (HIES) I997. Apia: Samoa Bureau of Statistics. Online at http://www.sbs.gov.ws/tabid/3430/ language/en-NZ/CensusandSurveys/I997HIESurvey.aspx [accessed 7 January 2OII]

2002 Household Income and Expenditure Survey 2002 Tabulation Report. Apia: Samoa Bureau of Statistics. Online at http:/www.sbs.gov.ws/ tabid/3429/language/en-NZ/CensusandSurveys/2002HIESurvey.aspx [accessed 7 January 20II]

Schaer, Cathrin

2002 The Religious Clashes Disturbing a Pacific Island Paradise. New Zealand Herald, 23 November.

Sialaoa, Amaramo

$200 \mathrm{I}$ Recent Economic Developments in Samoa. Pacific Economic Bulletin I 6 (I): 44-54.

2003 The Samoa Economy. Pacific Economic Bulletin I8 (2): I-I9.

So'o, Le'apai Lau Asofou, Unasa Leulu Felise Va'a, and Telesia Lafotanoa, editors

2006 Sāmoa National Human Development Report: Sustainable Livelihoods in a Changing Sāmoa. Apia: Centre for Samoan Studies, National University of Sāmoa.

State Department, United States

2003 International Religious Freedom Report 2003: Samoa. Washington DC: Bureau of Democracy, Human Rights and Labor, US Department of 
State. Available online at http://www.state.gov/g/drl/rls/irf/2003/243 I9 .htm [accessed I3 January 20I I]

Thornton, Alec, Maria Talaitupu Kerslake, and Tony Binns

20 Io Alienation and Obligation: Religion and Social Change in Samoa. Asia Pacific Viewpoint 5I (I): I-I6.

Treasury Department, Government of Samoa

2000 Statement of Economic Strategy, 2000-200I: Partnership for a Prosperous Society. Apia: Treasury Department, Government of Samoa.

2002 Strategy for Development of Samoa: Opportunities for All. Apia: Treasury Department, Government of Samoa.

Va'a, [Unasa] Leulu Felise

200 I Saili Matagi: Samoan Migrants in Australia. Suva: Institute of Pacific Studies, The University of the South Pacific.

Vatau, F, and F Alapati

2004 Alafua Church Opens. Samoa Observer Online. Apia, www.samoaobserver.ws/news/local/lno904/I009lnoo3.htm [accessed October 2005]

\section{Abstract}

Christian churches have assumed a central role in the social, economic, and political life of Sāmoa. Samoans are intensely committed to religion and express this commitment in participation in, and support for, the work of the churches. This article makes no comment on the rights of churches to seek contributions from their adherents, or of adherents to make contributions. However, the cash and labor contributed to churches has economic and social consequences for the trajectory of both village and national development. This article presents a profile of these contributions, a preliminary estimate of the scale of contributions to the Church, and an evaluation of the significance of these levels of support for the Church for Samoan village and national economies. The article also considers the sustainability of the trends outlined and some evidence of shifts in these historical patterns.

KEYWORDS: Sāmoa, churches, economic development, village development, national development, remittances 